\title{
The Effect of Employment Aspects on Poverty in Central Java Indonesia
}

\author{
By: \\ Nur Imam Saifuloh ${ }^{1)}$, Abdul Aziz Ahmad ${ }^{2)}$, Suharno ${ }^{3)}$ \\ ${ }^{1,2,3)}$ Faculty of Economics and Business, Universitas Jenderal Soedirman \\ ${ }^{3)}$ Email: suharno@unsoed.ac.id
}

\begin{abstract}
One way to tackle the problem of poverty is by understanding the labor aspects. This study aims to analyze the effect of employment aspects such as labor force participation rate, open employment rate and regional minimum wage on the poverty rate. This study used annual time series data between 2013-2017 of 15 regencies included in the red zone of poverty in Central Java Province. The best model to analyze data in this study is random effect model. The results show that labor force participation rate and open employment rate have positive and significant effect on poverty, while regional minimum wage has negative and significanteffect on poverty. The findings imply that the workforce should be well prepared to work or to create their own jobs andminimum wage should be increased.
\end{abstract}

Keywords: Poverty, Employment, Random Effect Model.

\begin{abstract}
ABSTRAK
Salah satu cara untuk mengatasi masalah kemiskinan adalah dengan memahami aspek tenaga kerja. Penelitian ini bertujuan untuk menganalisis pengaruh aspek ketenagakerjaan seperti tingkat partisipasi angkatan kerja, tingkat lapangan kerja terbuka dan upah minimum regional terhadap tingkat kemiskinan. Penelitian ini menggunakan data deret waktu tahunan antara 2013-2017 pada 15 kabupaten yang termasuk dalam zona merah kemiskinan di Provinsi Jawa Tengah. Model terbaik untuk menganalisis data dalam penelitian ini adalah model efek acak. Hasil penelitian menunjukkan bahwa tingkat partisipasi angkatan kerja dan tingkat lapangan kerja terbuka berpengaruh positif dan signifikan terhadap kemiskinan, sedangkan upah minimum regional berpengaruh negatif dan signifikan terhadap kemiskinan. Temuan ini menyiratkan bahwa tenaga kerja harus dipersiapkan dengan baik untuk bekerja atau untuk menciptakan pekerjaan mereka sendiri dan upah minimum harus ditingkatkan.
\end{abstract}

Kata kunci: Kemiskinan, Pekerjaan, Model Efek Acak.

\section{INTRODUCTION}

Poverty is a multidimensional development problem because it is based on diverse human needs and aspects. Experts and institutions have different opinion about the definition of poverty based on different perspectives and empirical studies (Beik and Laily, 2015). However, there is a consensus that poverty is the condition of inability to fulfill the basic needs or those who live below poverty line.

Poverty measurement in Indonesia refers to the concept of poverty delivered by the Central Bureau of Statistics. One is categorized as poor whenhe/she has an average monthly per capita expenditure below the poverty line (Central Bureau of Statistics, 2017c). Central Bureau of Statistics notes that the poverty rate of Indonesia continued to decline both in terms of the number of poor people and the poverty rate over five years as shown at Figure 1. 


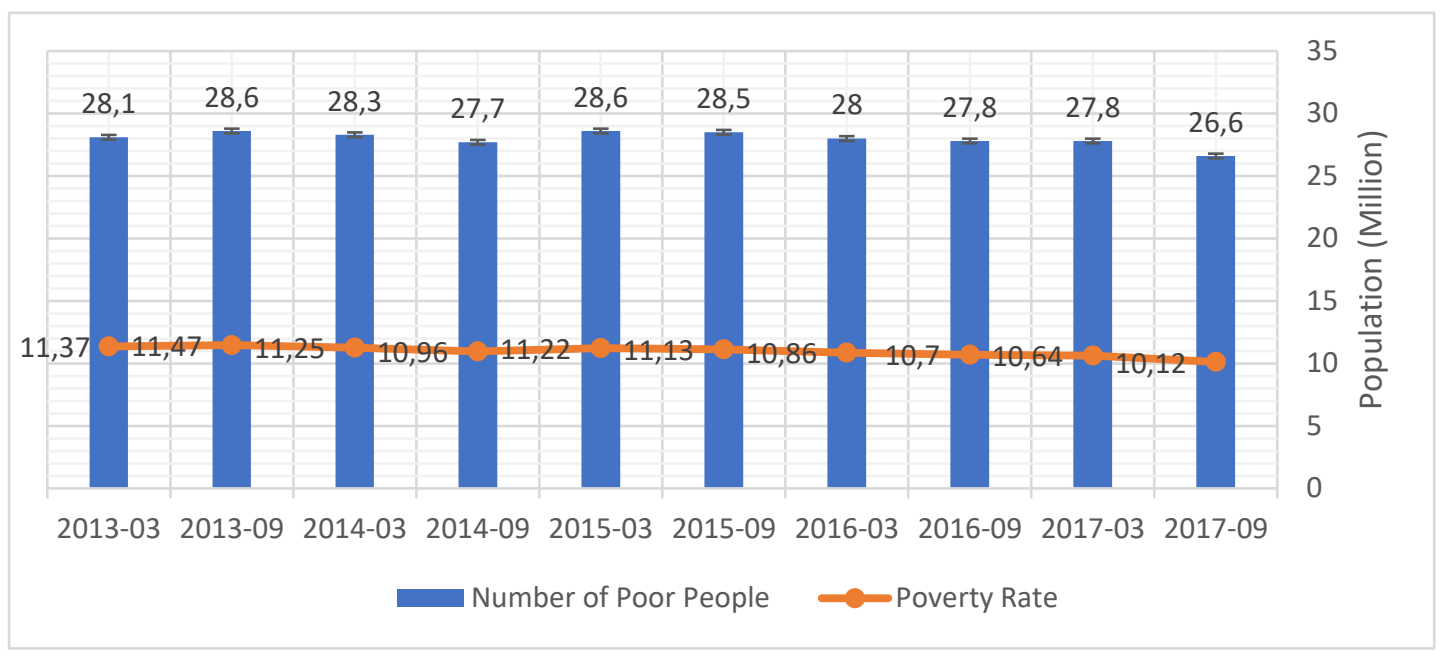

Figure 1. Number of Poor People and Poverty Rate of Indonesia 2013-2017

Source: Central Bureau of Statistics, 2019

Poverty rate decline to 9.92 percent with number of poor people of 25.95 million in March 2018. This phenomenon is also interesting to observe when it is related to distribution by island.

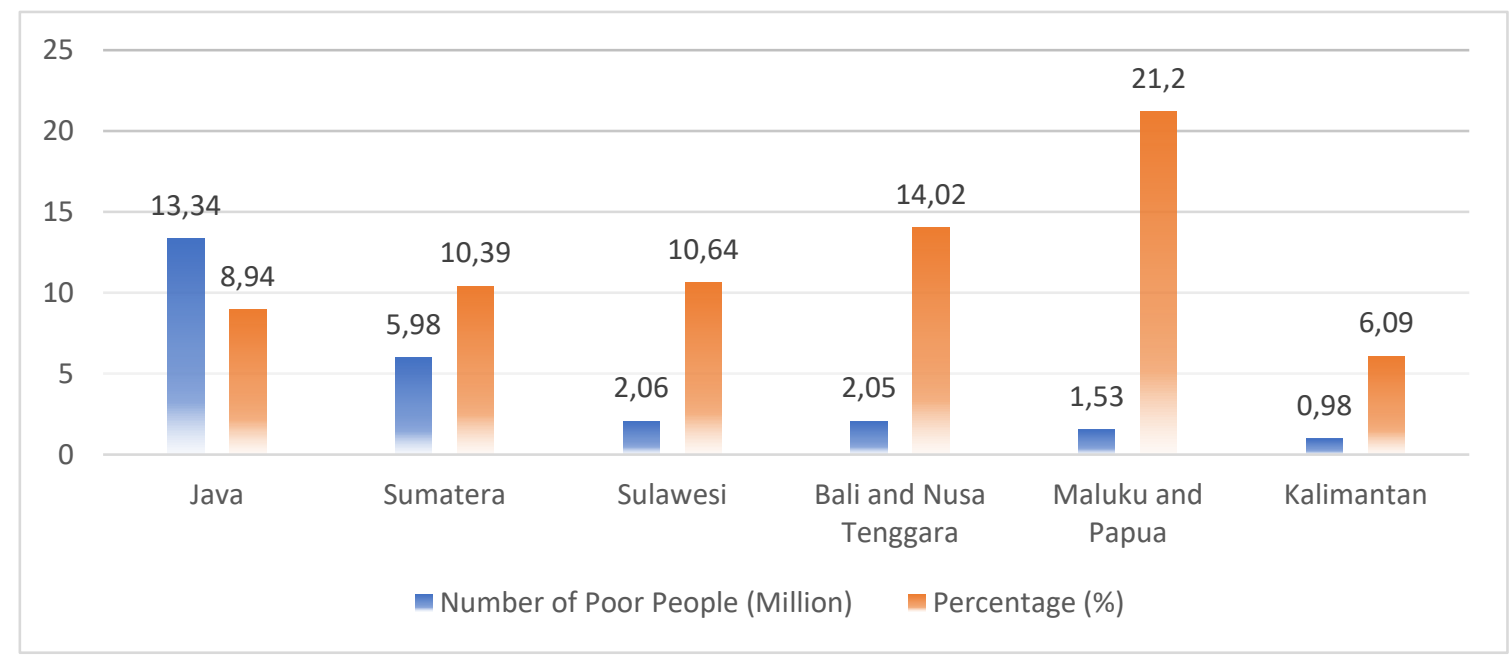

Figure 2. Distribution of Poverty in Indonesia 2018

Source: Central Bureau of Statistics, 2018b

Based on Figure 2, Maluku and Papua are islands with the highest poverty rate as compared to the other islands in Indonesia. However, the number of poor people in Maluku and Papua is only 1.53 million. On the contrary, the percentage of poverty on Java is 8.94 percent (below Maluku and Papua) but the number of poor people is 13.34 million. It is the highest number of poor people among other islands. Poverty rateon Java is describe at Figure 3.

Figure 3 shows that the highest poverty rate of 12.13 percent is observed in Yogyakarta Province. Central Java ranks second with the poverty rate of 11.32 percent. This study focuses on Central Java because its Poverty Gap Index- $\mathrm{P}^{1}{ }^{1}(2.21)$ is quite high, meaning that the average expenditure of the poor is away from the poverty line. In addition, the Poverty Severity Index-p2 ${ }^{1}$ of Central Java is 0.57 percent higher than Yogyakarta ( 0.55 percent).

In Central Java there are 15 regencies included in the red zone of poverty because have the poverty rate above the provincial figure (11.32 percent) and national figure ( 9.82 percent) as shown at Figure 4. 


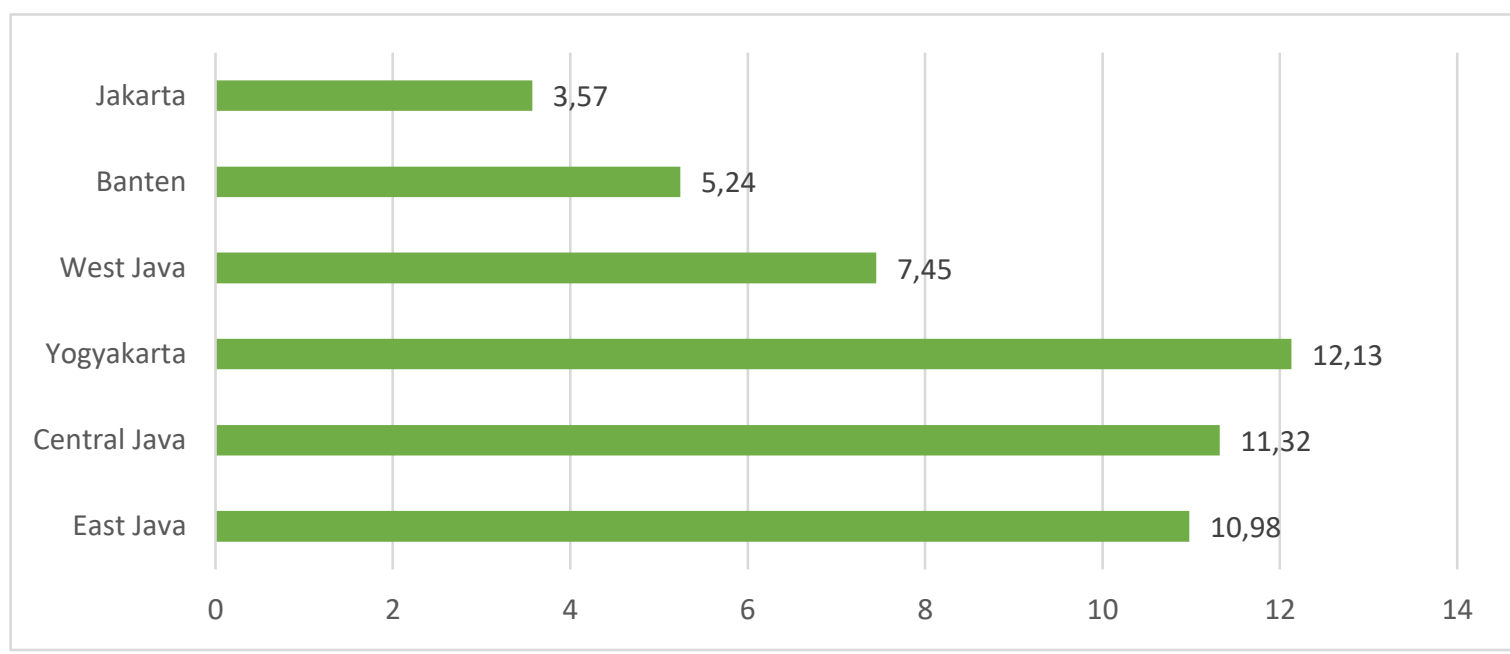

Figure 3. Poverty Rate by Provinces on Java 2018

Source: Central Bureau of Statistics, 2018b

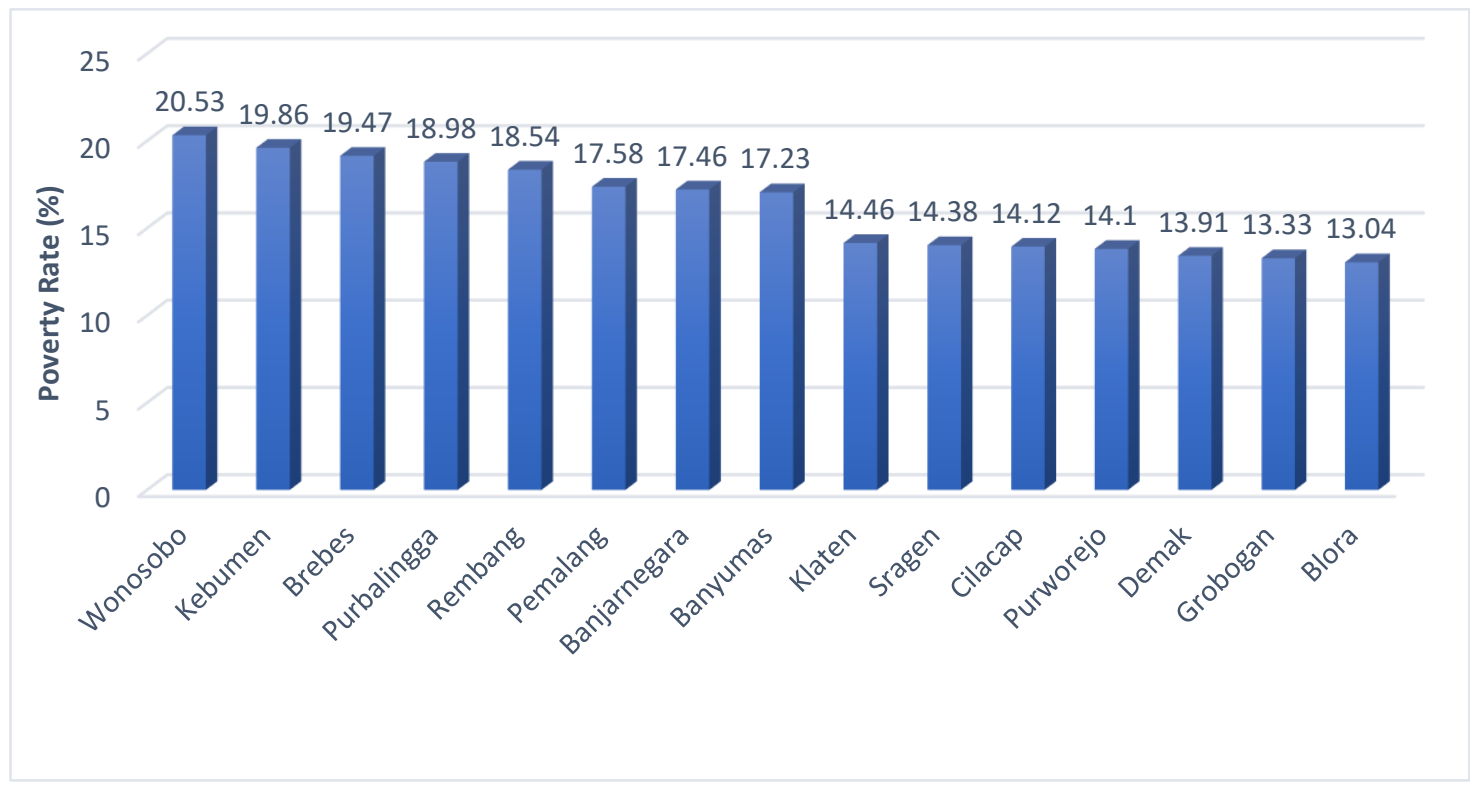

Figure 4. Regenciesof Central Java in Red Zone of Poverty Source: Central Bureau of Statistics, 2018a

One way to tackle poverty is understand labor aspects. Human as labor has a role in managing production factors. Production factors other than human beings will not provide full benefits for welfare if human as managers do not have capabilities. Variables included in the aspect of employment are wages, working age population, workforce population, non-workforce population, working population and unemployed population.

Previous researches only partially analyze variables in the labor aspect. Therefore, this study examined poverty by using labor variables comprehensively as measured by productivity, unemployment, and wages so that the results can be interpreted more deeply. Productivity is measured through the labor force participation rate which indicates the percentage of the working age population that is economically active in a country / region. Sasana (2009) and Aimon (2012) studies show that labor force participation rate can improve welfare and reduce poverty. The higher labor force participation rate means higher supply of labor. Based on the description, the first hypothesis can be proposed as follows:

$H_{1}$ : Labor force participation rate has a negative and significant effect on poverty. 
Unemployment is measured by the open unemployment rate which indicates the percentage of the workforce included in unemployment. Lang (2012) and Anggadini (2015) mentioned that the higher the unemployment rate the higher the poverty rate. Based on the description, the second hypothesis can be proposed as follows:

$\mathrm{H}_{2}$ : Open unemployment rate has a positive and significant effect on the poverty.

Wage is measured by regional minimum wage. The research conducted by Sen (2011) and Niswati (2014) mentioned that higher regional minimum wage will lead to increased welfare which means that regional minimum wage can reduce poverty because regional minimum wage describes the ability of population in region to fulfill their needs. Then, the third hypothesis can be formulated as follows:

$H_{3}$ : Regional minimum wage has a negative and significant effect on the poverty.

\section{ANALYTICAL METHOD}

This study used a quantitative research approach. There are two variables in this study; the dependent variable is poverty, and the independent variables consist of TPAK, TPT and UMK.Data were obtained from BPS publications and other documents that support the research. The data is classified as panel (pool) data because it merges of 15 regencies as cross section data and annual data from 2013 - 2017. There are three methods that can be used to estimate panel data namely Common Effect Model (CEM), Fixed Effect Model (FEM), and Random Effect Model (REM). The selection of the panel data regression model is carried out with the best and appropriate model specification test consisting of the Chow test to choose between CEM or FEM model, the Hausman test to select FEM or REM model if the Chow test results decide FEM. If the Chow test results decide to choose CEM, the Langrange Multiplier (LM) test is used to choose between CEM and REM (Widarjono, 2009).

Basic model of the research on the effect of TPAK, TPT and UMK toward on poverty by using data panel is as follow:

$$
\mathrm{P}_{\mathrm{it}}=\beta_{0}+\beta_{1} \mathrm{TPAK}_{\mathrm{it}}+\beta_{2} \mathrm{TPT}_{\mathrm{it}}+\beta_{3} \mathrm{UMK}_{\mathrm{it}}+\mathrm{e}_{\mathrm{it}}
$$

$\begin{array}{ll}\text { Where } & \\ \text { P } & : \text { Poverty } \\ \text { TPAK } & : \text { Workforce Participation Rate } \\ \text { TPT } & : \text { Open Unemployment Rate } \\ \text { UMK } & : \text { Regency Minimum Wage } \\ \mathrm{e} & : \text { Error Term } \\ \mathrm{i} & : \text { Regencies } \\ \mathrm{t} & : \text { Annual Data (2013-2017) }\end{array}$

Statistical tests are intended to measure the goodness of model (goodness of fit). A model has advantages and disadvantages if applied in difference cases of problems (Gujarati and Porter, 2012). Statistical test consists of coefficient of determination, $F$ test and $t$ test. Coefficient of determination gives the percentage of total variation in the dependent variable $(Y)$ which is explained by the independent variable $(X)$. $F$ test is used to determine the simultaneous effect of all independent variables contained in the model on the dependent variable. The $t$ test is used to show the extent to which the independent variable individually explains the variation of the dependent variable. 
RESULTS AND DISCUSSION

Description of Variables

Table 1. Poverty Rate of 15 Regencies in the Red Zone of Poverty in Central Java Province

\begin{tabular}{lccccc}
\hline Regency & 2013 & 2014 & 2015 & 2016 & 2017 \\
\hline Cilacap & 15.24 & 14.21 & 14.39 & 14.12 & 13.94 \\
Banyumas & 18.44 & 17.45 & 17.52 & 17.23 & 17.05 \\
Purbalingga & 20.53 & 19.75 & 19.70 & 18.98 & 18.80 \\
Banjarnegara & 18.71 & 17.77 & 18.37 & 17.46 & 17.21 \\
Kebumen & 21.32 & 20.50 & 20.44 & 19.86 & 19.60 \\
Purworejo & 15.44 & 14.41 & 14.27 & 13.91 & 13.81 \\
Wonosobo & 22.08 & 21.42 & 21.45 & 20.53 & 20.32 \\
Klaten & 15.60 & 14.56 & 14.89 & 14.46 & 14.15 \\
Sragen & 15.93 & 14.87 & 14.86 & 14.38 & 14.02 \\
Grobogan & 14.87 & 13.86 & 13.68 & 13.57 & 13.27 \\
Blora & 14.64 & 13.66 & 13.52 & 13.33 & 13.04 \\
Rembang & 20.97 & 19.50 & 19.28 & 18.54 & 18.35 \\
Demak & 15.72 & 14.60 & 14.44 & 14.10 & 13.41 \\
Pemalang & 19.27 & 18.44 & 18.30 & 17.58 & 17.37 \\
Brebes & 20.82 & 20.00 & 19.79 & 19.47 & 19.14 \\
\hline Central Java & 14,5 & 14.02 & 13.45 & 13.23 & 12.62 \\
\hline Indonesia & 11.41 & 11.105 & 11.175 & 10.78 & 10.38 \\
\hline
\end{tabular}

Source: Central Bureau of Statistics, 2018a

Over the last 5 years, the 15 regencies above have higher poverty rates than the provincial and national figures which lead them to be included in the red zone of poverty. In general, there is a decrease in the level of poverty every year in the study area. However, this decline was also followed by the provincial and national regions, so that despite the decline, there were still included in the red zone of poverty. In terms of employment (TPAK, TPT, TKK, and UMK), the following are the data in those regencies.

Table 2. TPAK of 15 Regencies included in the Red Zone of Poverty of Central Java Province

\begin{tabular}{lcccccc}
\hline \multirow{2}{*}{ Regency } & \multicolumn{5}{c}{ Year (Percent) } & \multirow{2}{*}{ Average (Percent) } \\
\cline { 2 - 5 } Cilacap & 2013 & 2014 & 2015 & 2016 & 2017 & 64.13 \\
Banyumas & 66.42 & 63.24 & 62.39 & 62.39 & 66.22 & 62.79 \\
Purbalingga & 64.17 & 64.27 & 60.17 & 60.17 & 65.19 & 70.50 \\
Banjarnegara & 73.76 & 70.95 & 68.05 & 68.05 & 71.68 & 73.00 \\
Kebumen & 73.63 & 75.20 & 72.61 & 72.61 & 70.95 & 70.78 \\
Purworejo & 71.63 & 74.57 & 70.43 & 70.43 & 66.84 & 68.42 \\
Wonosobo & 71.48 & 68.44 & 68.86 & 68.86 & 64.48 & 73.06 \\
Klaten & 69.50 & 73.90 & 74.75 & 74.75 & 72.37 & 69.21 \\
Sragen & 73.10 & 70.46 & 67.79 & 67.79 & 66.93 & 72.03 \\
Grobogan & 73.79 & 71.44 & 71.91 & 71.91 & 71.12 & 72.56 \\
Blora & 73.36 & 74.65 & 71.09 & 71.09 & 72.62 & 71.15 \\
Rembang & 75.50 & 68.50 & 70.77 & 70.77 & 70.21 & 70.55 \\
Demak & 73.23 & 68.13 & 70.31 & 70.31 & 70.78 & 61.26 \\
Pemalang & 68.58 & 67.86 & 51.06 & 51.06 & 67.73 & 65.63 \\
Brebes & 66.82 & 69.15 & 63.32 & 63.32 & 65.57 & 66.30 \\
\hline
\end{tabular}

Source: Central Bureau of Statistics, 2018a 
TPAK is obtained from the calculation of the number of labor force (work and unemployment) divided by the number of working age population multiplied by 100 percent. Higher TPAK shows higher labor supply available to produce goods and services. Based on Table 2 the highest TPAK during the 5year period is occupied by Wonosobo Regency, which is 73.06 percent, while the lowest TPAK was observed in Demak Regency (61.26 percent).

Table 3. TPT of 15 Regencies included in the Red Zone of Poverty of Central Java Province

\begin{tabular}{lcccccc}
\hline \multirow{2}{*}{ Regency } & \multicolumn{5}{c}{ Year (Percent) } & \multirow{2}{*}{ Average (Percent) } \\
\cline { 2 - 5 } Cilacap & 2013 & 2014 & 2015 & 2016 & 2017 & 6.95 \\
Banyumas & 6.76 & 5.65 & 8.01 & 8.01 & 6.30 & 5.64 \\
Purbalingga & 5.46 & 5.37 & 6.37 & 6.37 & 4.62 & 5.17 \\
Banjarnegara & 5.72 & 5.13 & 4.84 & 4.84 & 5.33 & 4.63 \\
Kebumen & 4.26 & 4.06 & 5.05 & 5.05 & 4.72 & 4.14 \\
Purworejo & 3.58 & 3.25 & 4.14 & 4.14 & 5.58 & 4.37 \\
Wonosobo & 5.11 & 5.10 & 4.01 & 4.01 & 3.64 & 4.86 \\
Klaten & 5.83 & 5.34 & 4.47 & 4.47 & 4.18 & 3.90 \\
Sragen & 5.38 & 4.75 & 2.51 & 2.51 & 4.35 & 5.06 \\
Grobogan & 5.70 & 6.04 & 4.51 & 4.51 & 4.55 & 4.74 \\
Blora & 6.04 & 4.25 & 5.22 & 5.22 & 2.95 & 4.55 \\
Rembang & 6.25 & 4.30 & 4.68 & 4.68 & 2.85 & 4.42 \\
Demak & 5.98 & 5.23 & 3.86 & 3.86 & 3.19 & 8.43 \\
Pemalang & 7.04 & 5.17 & 12.74 & 12.74 & 4.47 & 6.53 \\
Brebes & 6.55 & 7.44 & 6.53 & 6.53 & 5.59 & 8.02 \\
\hline
\end{tabular}

Source: Central Bureau of Statistics, 2018a

Table 4. UMK in Regencies included in the Red Zone of Poverty of Central Java Province

\begin{tabular}{lrrrrr}
\hline \multirow{2}{*}{ Regency } & \multicolumn{5}{c}{ Year (IDR) } \\
\cline { 2 - 6 } & 2013 & \multicolumn{1}{c}{2014} & \multicolumn{1}{c}{2015} & 2016 & 2017 \\
\hline Cilacap & 887,667 & $1,016,600$ & $1,195,600$ & $1,608,000$ & $1,693,600$ \\
Banyumas & 877,500 & $1,000,000$ & $1,100,000$ & $1,350,000$ & $1,461,400$ \\
Purbalingga & 896,500 & $1,028,000$ & $1,101,600$ & $1,377,500$ & $1,522,500$ \\
Banjarnegara & 835,000 & 920,000 & $1,112,500$ & $1,265,000$ & $1,370,000$ \\
Kebumen & 835,000 & 975,000 & $1,157,500$ & $1,324,600$ & $1,433,900$ \\
Purworejo & 849,000 & 910,000 & $1,165,000$ & $1,300,000$ & $1,445,000$ \\
Wonosobo & 880,000 & 990,000 & $1,166,000$ & $1,326,000$ & $1,457,100$ \\
Klaten & 871,500 & $1,026,600$ & $1,170,000$ & $1,400,000$ & $1,528,500$ \\
Sragen & 864,000 & 960,000 & $1,105,000$ & $1,300,000$ & $1,422,585$ \\
Grobogan & 842,000 & 935,000 & $1,160,000$ & $1,305,000$ & $1,435,000$ \\
Blora & 932,000 & $1,009,000$ & $1,180,000$ & $1,328,000$ & $1,438,100$ \\
Rembang & 896,000 & 985,000 & $1,120,000$ & $1,300,000$ & $1,408,000$ \\
Demak & 995,000 & $1,280,000$ & $1,535,000$ & $1,745,000$ & $1,900,000$ \\
Pemalang & 908,000 & $1,066,000$ & $1,193,400$ & $1,325,000$ & $1,460,000$ \\
Brebes & 859,000 & $1,000,000$ & $1,166,500$ & $1,310,000$ & $1,418,100$ \\
\hline
\end{tabular}

Source: Central Bureau of Statistics, 2018a

Open unemployment is a situation where a person classified as workforce is actively looking for work at a certain wage level but cannot get the job he / she wants (Sukirno, 2010). The Open Unemployment Rate (TPT) is obtained from a ratio of the number of unemployed with the number of labor force in an area. Higher TPT indicates that more labor is not absorbed in the labor market. Table 
3 shows that the highest TPT is occupied by Demak Regency ( 8.43 percent) and the lowest is Klaten Regency (3.90 percent).

Different condition is shown in terms of Regency Minimum Wage (UMK). Based on Table 4 Demak Regency has the highest UMK Rp1,900,000 in 2017, while the lowest is occupied by Banjarnegara Regency (Rp1,370,000).

\section{Panel Data Regression Model}

The result of Chow test to compare and choose the best model between CEM and FEM is presented at Table 5.

Table 5. Chow Test

\begin{tabular}{lccc}
\hline Effects Test & Statistic & d.f. & Prob. \\
\hline Cross-section F & 382.866848 & $(14.57)$ & 0.0000 \\
Cross-section Chi-square & 341.570344 & 14 & 0.0000 \\
\hline
\end{tabular}

Source: Chow Test Results, 2019

Based on Table 5, the value of the prob Chi-square cross-section is 0.000 . The significance level of $\alpha$ used in this study is 0.05 so that the results of this test state that the panel data regression model using the FEM approach is better to use than CEM. Furthermore, to find out which model is best between FEM and REM, the Hausman test is carried out as shown at Table 6.

Table 6. Hausman Test

\begin{tabular}{lccc}
\hline Test Summary & Chi-Sq. Statistic & Chi-Sq. d.f. & Prob. \\
\hline Cross-section random & 1.647964 & 3 & 0.6486 \\
\hline
\end{tabular}

Source: Hausman Test Results, 2019

Based on Table 6 the prob value ofCross-Section Random is 0.6486. If a significance level of $\alpha$ is used for 0.05 , it can be concluded that the probability value is greater than $\alpha$. This means that the random effects model is more appropriate to be used in this study than the fixed effects model.

Based on the results of the tests, the equation of the estimator model for poverty levels in 15 regencies included in the Central Java 2013-2017 is

$$
\operatorname{LogP}_{i t}=1.98+0.07 \operatorname{LogTPAK}_{i t}+0.03 \operatorname{LogTPT}_{i t}-0.15 \operatorname{LogUMK}_{\text {it }}
$$

Where:

$\begin{array}{lll}\log (P) & : & \text { Poverty } \\ \log (T P A K) & : & \text { Workforce Participation Rate } \\ \log (\text { TPT }) & : & \text { Open Unemployment Rate } \\ \log (\text { UMK }) & : & \text { Regional Minimum Wage } \\ \text { I } & : & \text { Regencies } \\ T & : & \text { Year/annual }\end{array}$

Coefficient of determination (R-square) value is 0.793989 . It shows that 79.39 percent of the variation in poverty can be explained by the independent variables of TPAK, TPT and UMK. F test statistic values are presented at Table 7.

Table 7. F Test

\begin{tabular}{lc}
\hline F Statistic & 58.77 \\
Prob. (F Statistic) & 0.000000 \\
\hline
\end{tabular}

Source: Random Effects Model, 2019

The $F$ value is 91.21402 , while the value of $F$ table can be found by the value of numerator degree of freedom (DF1) from total independent variables and denominator degree of freedom (DF2) i.e. total 
number of samples minus number of independent variables minus $1(n-k-1)$. With confidence level of 95 percent, the value of DF1 $=3$ and the value of DF2 $=70(75-3-1)$, then the value of $F$ table is 2.733647. F statistic is higher than $\mathrm{F}$ table $(91.21402>2.502656)$ which means that the independent variables (TPAK, TPT and UMK) simultaneously influence the dependent variable (poverty). The $t$ statistic of each independent variable can be seen at Table 9 .

Table 8. Result of $t$ Test

\begin{tabular}{lcc}
\hline Variable & Coefficient & t-Statistic \\
\hline Log(TPAK) & 0.073980 & 1.419937 \\
Log(TPT) & 0.033433 & 2.885258 \\
Log(UMK) & -0.150724 & -11.92825 \\
\hline
\end{tabular}

Source: Random Effects Model, 2019

With confidence level of 95 percent, t statistic of TPAK is smaller than t-table $(1.419937<$ 1.66666). It means that TPAK does not have significant effect on poverty. This study does not find significant effect of TPAK on the poverty rate in 15 Regencies included in red zone of poverty in Central Java 2013 - 2017. These results is contrary to the previous research by Merrick (2002) and Sasana (2009) indicating that TPAK has negative and significant on poverty. According to Merrick (2002) and Sasana (2009), the association between TPAK and poverty can be explained as working population can reduce poverty rate and dependency ratio. It is based on the assumption that working people will have income to fulfill their daily needs. Therefore, Sasana (2009) argued that the absorption of population into employment can reduce the number of poor people and increase welfare rate. However, the wage could be lower than what it is supposed to be. In addition, household size could be big which leads to lower income per capita at the household level. In other words, the insignificant effect could be due to the fact that higher participation in workforce does not necessarily lead to lower poverty due to low wage and/or big household size.

In addition, $\mathrm{t}$ statistic of TPT is greater than t-table $(2.88528>1.6666)$. It means that TPT has a positive and significant effect on poverty. The coefficient of TPT has a positive value of 0.033433 which means that one percent increase in TPT will cause an increase in the poverty rate of 0.033433 percent. The finding of this research supports Lang (2012) and Anggadini (2015) who find that unemployment has a positive effect on poverty. The higher unemployment that occurs in an area causes the poverty rate to increase. Unemployed people are actually included to workforce that is ready to carry out economic activities. However, unavailability of employment, lack of expertise, inadequate qualifications needed by employers caused the population to have no job. Unemployed people have no income to fulfill the basic needs.

The $t$ statistic of UMK is greater than $t$ table $(-11.92825>1.6666)$ meaning that UMK has a negative and significant effect on poverty. The coefficient of UMK is -0.150724 which indicates that one percent increase in UMK will decrease poverty rate by 0.150724 percent. The finding of this research supports Sen (2011) and Lang (2012) who find that UMK has a negative effect on poverty. Higher UMK will decrease poverty rate because as they argued, minimum wage gives guarantee to workers to fulfill their basic needs.

\section{CONCLUSION}

Based on the results, TPAK does not have significant effect by stastistic on poverty. The insignificant effect could be due to the fact that higher participation in workforce does not necessarily lead to lower poverty due to low wage and/or big household size. TPT has a positive and significant effect on poverty, whereas UMK has a negative and significant effect on poverty. The results imply that the workforce should be well prepared to be able to enter labor market and to increase their income, or to create their own jobs. Furthermore, UMK should be increased so as to improve welfare. 


\section{REFERENCES}

Aimon, H. (2012). Productivity, human resource investment, physical investment, job opportunities on poverty and economic growth in Indonesia. Journal of Economic Studies, 1(1), 209-218.

Anggadini, F. (2015). Analysis of the effect of life expectancy, literacy rate, open unemployment rate and gross regional domestic income per capita on poverty in districts / cities in Central Sulawesi Province in 2010-2013. Catalogis E-Journal, 3(7), 40-49.

Central Bureau of Statistics. (2017a). Indonesia in figures 2017. Jakarta. . (2017b). Central Java employment profile 2017. Semarang. . (2017c). Central Java Province in figures 2017. Semarang. . (2018a). Poverty of Central Java Province March 2018. Semarang. . (2018b). Profile of poverty in Indonesia March 2018. Jakarta.

Beik, I. S. \& Arsyianti, L. D. (2015). Construction of CIBEST model as measurement of poverty and welfare from Islamic perspective. Al-lqtishad Journal, 7(1), 87-104.

Gujarati, D. N. \& Porter, D. C. (2012). Econometrics basics (translated by Raden Carlos Mangunsong). Jakarta: Salemba Empat.

Lang. (2012). Poverty and the labor market. University of Sydney: Oxford Handbooks Online.

Merrick, T. W. (2002). Population and poverty: new views on an old controversy. International Family Planning Perspective, 28(1), 41-46.

Niswati, K. (2014). Factors affecting poverty in Special Region of Yogyakarta in 2003-2011. EkoRegional, 9(2), 82-89.

Sasana, H. (2009). The role of fiscal decentralization on economic performance in the regencies / cities of Central Java Province. Journal of Development Economics, 10(1), 103-124.

Sen, A. (2011). Teen employment, poverty, and the minimum wage: evidence from Canada. Labour Economics, 18(1), 36-47.

Law No. 13 of 2003 concerning manpower.

Widarjono, A. (2009). Econometrics: introduction and application. Yogyakarta: Ekonisia. 